\title{
Motivasi Peternak Dalam Mengikuti Program Asuransi Usaha Ternak Sapi (AUTS)
}

\author{
Ilmawati $^{1}$, Musdalifa Mahmud ${ }^{2}$, Syamsinar $^{2}$ \\ ${ }^{1}$ Dinas Peternakan dan Kesehatan Hewan Kabupaten Sinjai \\ ${ }^{2}$ Fakultas Pertanian, Universitas Islam Makassar \\ Email: ilma@gmail.com
}

Corresponding Author: Ilmawati, Dinas Peternakan dan Kesehatan Hewan Kab. Sinjai, Email: ilma@gmail.com

\begin{abstract}
ABSTRAK
Penelitian ini bertujuan untuk mengetahui (1) bagaimana pelaksanaan program Asuransi Usaha Ternak Sapi (AUTS) (2) motivasi peternak terhadap program Asuransi Usaha Ternak Sapi (AUTS) dan (3) Faktor Internal dan eksternal apa saja yang berhubungan dengan motivasi peternak pada program Asuransi Usaha Ternak Sapi (AUTS) di Kecamatan Tellulimpoe Kabupaten Sinjai. Penelitian ini dilaksanakan di Kecamatan Tellilimpoe, Kabupaten Sinjai. Pengumpulan data dilakukan melalui observasi, dan wawancara menggunakan kuisioner terhadap 41 responden/peternak yang dipilih secara acak sederhana. Data dianalisis dengan analisis statistik deskriptif berupa frekuensi, persentase, median, rataan skor dan total rataan skor. Data mengenai hubungan antara peubah dianalisis dengan menggunakan uji korelasi rank Spearman.Hasil Penelitian menunjukkan, pelaksanaan Program Asuransi usaha Ternak Sapi (AUTS) di Kecamatan Tellulimpoe berjalan dengan baik yang ditandai jumlah peserta (sapi) terbanyak di Kabupaten Sinjai yang berjumlah 992 pada Tahun 2017. terjadi peningkatan sebesar 164 peserta setiap tahunnya. Motivasi Peternak terhadap Program AUTS didasari atas keinginan untuk memenuhi kebutuhan dasar dengan nilai rataan skor responden sebesar 2,33 (tergolong sedang), kebutuhan berhubungan sosial dengan nilai rataan skor responden sebesar 2,68 (tergolong tinggi), dan pengembangan usaha dengan nilai rataan skor responden sebesar 2,95 (tergolong tinggi). Faktor internal peternak yang mempunyai hubungan cukup dengan motivasi peternak dalam mengikuti program AUTS adalah hubungan aspek sosial dengan umur responden ( $r=0,545)$, hubungan aspek kebutuhan dasar dengan jumlah tanggungan keluarga $(r=0,675)$ dan hubungan aspek pengembangan usaha dengan tingkat Pendidikan $(r=0,705)$. Sedangkan Faktor eksternal yang mempunyai hubungan kuat dengan motivasi peternak mengikuti program AUTS adalah aspek kebutuhan dasar $(0,601)$ dan pengembangan usaha $(0,580)$ adalah factor pasar..
\end{abstract}

Kata kunci: Perternak, sapi potong, Asuransi Ternak, Kabupaten Sinjai

\section{PENDAHULUAN}

Asuransi Pertanian adalah perjanjian antara petani dan pihak asuransi untuk mengikatkan diri dalam pertanggungan resiko usaha tani. sehingga keberlangsungan usaha tani dapat terjamin dan ini sangat penting bagi para petani untuk melindungi usaha taninya. Pada Tahun 2017, Kementerian Pertanian Melalui Direktorat Jenderal Prasarana dan Sarana Pertanian mengalokasikan kegiatan fasilitasi Asuransi Usaha Ternak Sapi (AUTS) dengan memberikan bantuan pembayaran premi asuransi usaha ternak sapi pembibitan dan atau pembiakan(Syafril., 2017). Tujuan dan sasaran Asuransi Usaha Ternak Sapi (AUTS) adalah untuk mengalihkan resiko kerugian usaha akibat sapi mengalami kematian dan atau kehilangan kepada pihak lain melalui skema pertanggungan asuransi. Sedangkan sasaran Asuransi Usaha Ternak sapi adalah terlindunginya peternak sapi dari kerugian usaha akibat kematian dan atau kehilangan supaya peternak dapat melanjutkan usahanya. Meskipun demikian, tidak semua peternak membuat keputusan mengikuti program Asuransi Usaha Ternak Sapi (AUTS), walaupun banyak peternak mengetahui bahwa usaha peternakan memiliki berbagai resiko dan kerugian (Balai Pengajian Teknologi Pertanian (BPTP), 2017). 
Suksesnya suatu program seperti program Asuransi Usaha Ternak Sapi (AUTS), khususnya di Kabupaten Sinjai tidak hanya ditentukan oleh tersedianya fasilitas atau sarana dan prasarana, modal dan alat bantu lainnya tetapi juga tergantung dari seberapa besar motivasi yang dimiliki oleh peternak tersebut. Motivasi merupakan salah satu aspek penentu keberhasilan dari adanya program AUTS (Dinas Peternakan Kab. Sinjai, 2017). Motivasi pada dasarnya adalah kondisi mental yang mendorong dilakukannya suatu tindakan (Action atau activities) dan memberikan kekuatan (Energy) yang mengarah kepada pencapaian kebutuhan (Asmirani, 2013).

Menurut Winardi (2004), rendah atau tingginya motivasi seseorang akan berdampak pada kecil atau besarnya skala usaha yang sedang dilakukannya. Terdapat tiga aspek dalam motivasi yaitu 1) keadaan yang mendorong. 2)Tingkah laku yang dibangkitkan dan diarahkan oleh keadaan tadi. 3) Tujuan yang menjadi arah dan dari tingkah laku. Jadi motif membangkitkan tingkah laku dan mengarahkannya pada pada tujuan yang sesuai. Selain itu faktor lain yang mempengaruhi motivasi peternak mengikuti AUTS dapat dikategorikan sebagai berikut: yaitu 1.) Faktor internal diantaranya : kebutuhan, rasa aman, pola pikir dan harga diri. Sedangkan Faktor Eksternal diantaranya tradisi, lingkungan, sosialisasi/penyuluhan, pendampingan, pengawalan dan deseminasi teknologi.

Pada kenyataannya pelaksanaan program Asuransi Usaha Ternak Sapi (AUTS) di Kabupaten Sinjai sejak Bulan Oktober tahun 2016 sampai sekarang yang dilaksanakan oleh Dinas Peternakan dan Kesehatan Hewan Kabupaten Sinjai, realisasinya masih sangat rendah apabila dilihat dari jumlah populasi ternak sapi potong yang ada di Kabupaten Sinjai Tahun 2017 yaitu mencapai, 105.718 ekor. Dan target Tahun 2017 yaitu 6000 ekor sapi yang terdaftar sebagai peserta AUTS namun hanya mencapai 4446 ekor sapi yang terdaftar sebagai peserta AUTS, walaupun data perkembangan jumlah peserta AUTS untuk 2 tahun terakhir menunjukkan peningkatan jumlah peserta AUTS. Berikut data perkembangan jumlah peserta AUTS untuk 2 tahun terakhir dapat dilihat pada tabel 1.

Tabel 1. Data perkembangan jumlah peserta AUTS 2016-2017

\begin{tabular}{cccccc}
\hline \multirow{3}{*}{ No } & Kecamatan & \multicolumn{3}{c}{ Tahun 2016 } & Tahun 2017 \\
\cline { 3 - 6 } & & $\begin{array}{c}\text { Jumlah } \\
\text { Peterna } \\
\text { k }\end{array}$ & $\begin{array}{c}\text { Jumlah Peserta } \\
\text { AUTS (Sapi) }\end{array}$ & $\begin{array}{c}\text { Jumlah } \\
\text { Peternak }\end{array}$ & $\begin{array}{c}\text { Jumlah Peserta AUTS } \\
\text { (Sapi) }\end{array}$ \\
\cline { 3 - 6 } & 124 & 480 & 146 & 601 \\
& Sinjai Barat & 31 & 121 & 126 & 211 \\
SinjaiBorong & 79 & 499 & 246 & 345 \\
Sinjai Selatan & 243 & 244 & 582 & 992 \\
Tellulimpoe & 162 & 236 & 371 & 618 \\
Sinjai Timur & 178 & 160 & 129 & 338 \\
Sinjai Tengah & 70 & 74 & 390 & 540 \\
Sinjai Utara & 57 & $\mathbf{1 8 6 3}$ & $\mathbf{2 4 6 8}$ & $\mathbf{4 4 4 6}$ \\
Bulupoddo & $\mathbf{9 8 1}$ &
\end{tabular}

Sumber: Dinas Peternakan dan kesehatan Hewan Kab. Sinjai, 2018

Banyak penelitian yang mengkaji tentang motivasi peternak, seperti Faktor-faktor yang mempengaruhi pengambilan keputusan peternak ikut serta dalam program SPR untuk meningkatkan pengetahuan tentang pengolahan pakan, mengontrol kesehatan ternak, ikut-ikutan, nilai sosial kebersamaan, pemberian pakan pada dukungan dari pemerintah, recording lebih mudah, adanya bantuan, mencari pengetahuan dan bentuk partisipasi masyarakat (Nita Adillah Pratiwi, 2017), Kemitraan yang menjadi salah satu factor hubungan sangat erat dengan motivasi peternak (Sri Wahyuni, 2017) dan penentuan standard setiap program dan penyesuaiannya dengan kondisi lokal spesifik agar program dapat berkembang kearah swakelola bercorak agribiisnis secara bertahap (Siregar, 2016). Akan Tetapi belum ada penelitian yang focus mengkaji motivasi peternak dalam mengikuti Asuransi Usaha Ternak Sapi (AUTS) khususnya di Kabupaten Sinjai. Berdasarkan hal tersebut diatas maka penulis merasa tertarik untuk mengkaji bagaimana pelaksanaan program Asuransi Usaha Ternak Sapi (AUTS) di Kec. Tellulimpoe yang selama ini di laksanakan, apa motivasi peternak terhadap program Asuransi Usaha Ternak Sapi (AUTS) di Kecamatan Tellulimpoe Kabupaten Sinjai dan Faktor Internal dan eksternal apa saja yang mempengaruhi motivasi peternak terhadap program Asuransi Usaha Ternak Sapi (AUTS) di Kecamatan Tellulimpoe Kabupaten Sinjai. 


\section{METODE PENELITIAN}

Jenis penelitian yang digunakan dalam penelitian ini adalah jenis penelitian campuran (mix method), yaitu penelitian yang menggunakan pendekatan kuantitatif sebagai pendekatan utama (quatitative dominant) dan kualitatif sebagai pendukung (qualitative less) yang bertujuan untuk mendeskripsikan variabel-variabel motivasi peternak terhadap program AUTS (Rasyid, 2006).Penelitian ini dilaksanakan di Kecamatan Tellulimpoe Kabupaten Sinjai pada Bulan Oktober sampai November 2018 terhadap peternak yang memelihara sapi potong yang masuk peserta Asuransi Usaha Ternak Sapi (AUTS),dengan pertimbangan bahwa Kecamatan Tellulimpoe merupakan kecamatan dengan jumlah populasi ternak sapi potong yang terbesar dan jumlah peternak yang terbanyak yang mengikuti program Asuransi Usaha Ternak Sapi (AUTS). Populasi dalam penelitian ini adalah seluruh Peternak yang mengikuti program Asuransi Usaha Ternak Sapi (AUTS) yang terdapat di Kecamatan Tellulimpoe, Kabupaten Sinjai, yang berjumlah 582 peternak peserta Ausansi Usaha Ternak Sapi (AUTS). Sampel didapatkan melalui rumus slovin dan penentuan sampelnya dilakukan dengan cara menentukan sampel dan populasi yang memenuhi karakteristik tertentu sebagai pembatas. Berhubung karena populasi cukup besar, maka dilakukan pengambilan sampel. Berdasarkan hasil perhitungan tersebut maka jumlah sampel yang digunakan pada penelitian ini adalah sebanyak 42 orang responden peserta AUTS yang ada di Kecamatan Tellulimpoe, Kabupaten Sinjai. Sampel ini dipilih secara acak.

Sumber data yang digunakan pada penelitian ini sebagai berikut : (1) Data primer, yaitu data yang bersumber dari wawancara langsung dengan peternak yang mengikuti program Asuransi Usaha Ternak Sapi (AUTS) mengenai variabel-variabel penelitian dengan mengggunakan bantuan kuisioner dan (2) Data Sekunder yaitu data yang diperoleh dari instansi yang terkait seperti data monografi desa data populasi ternak sapi potong dan data asuransi usaha ternak sapi potong (AUTS) di Kecamatan Tellulimpoe Kabupaten Sinjai. Analisis yang digunakan dalam penelitian ini, berdasarkan tujuan penelitian yang dilakukan, maka digunakan beberapa metode, yaitu : Metode Kualitatif : Metode yang menjelaskan teori sebagai landasan berpikir serta adanya wawancara dan informasi dari hasil-hasil pengamatan penulis yang disimpulkan menjadi suatu data yang kemudian dianalisis. Metode ini digunakan untuk menjawab rumusan masalah 1 dan 2, dan Metode Kuantitatif: Analisis data guna menjawab masalah dan tujuan penelitian yang telah dirumuskan dengan menggunakan analisis statistik deskriptif berupa frekuensi, persentase, median, rataan skor dan total rataan skor. Data mengenai hubungan antara peubah dianalisis dengan menggunakan uji korelasi rank Spearman: Metode ini digunakan untuk menjawab rumusan masalah 3. Korelasi rank spearman yaitu : suatu teori yang digunakan untuk menetukan korelasi peringkat spearman antara dua faktor (variabel). Korelasi rank dipergunakan apabila pengukuran kuantitatif secara eksak tidak mungkin/sulit dilakukan misalnya mengukur tingkat moral,tingkat kesenangan,tingkat motivasi.

Rumus Korelasi Rank Spearman :

$$
r s=1-\frac{6 \sum d^{2}}{n\left(n^{2}-1\right)}
$$

Dimana:

$$
\begin{array}{ll}
\mathrm{rs} & \text { : nilai koefisien Korelasi Spearman } \\
\mathrm{d} & \text { : selisih antara kedua peringkat peubah } \\
\mathrm{n} & \text { : banyaknya pengamatan }
\end{array}
$$

\section{HASIL DAN PEMBAHASAN}

\section{Karakteristik Identitas Responden Umur Responden}

Umur merupakan faktor penentu dalam segala aktifitas masing-masing responden guna memaksimalkan tenaga kerja dan sumber daya yang dimiliki untuk digunakandalam usaha peternkan mereka. Dari hasil penelitian ternyata umur responden cukup bervariasi antara 23 tahun sampai dengan 60 tahun petani responden sebagian besar terdistribusi pada kelompok umur 44 - 50 tahun sebanyak 15 orang (35,7\%), kemudian di ikuti umur $37-43$ tahun sebanyak 12 orang (28.6\%). Sedangkan golongan umur yang terkecil dari 42 orang responden adalah umur $23-29$ tahun dan umur 58 - 64 tahun sebesar 1 orang responden atau dengan nilai persentase sebesar $2.4 \%$.

\section{Pendidikan Formal}


Tingkat pendidikan petani responden dalam penelitian yang paling besar jumlahnya adalah SD dengan jumlah 19 orang resonden dengan persentase sebesar 45,2 \%, dibawah jumlah responden yang mengecap tingkat pendidikan SMA dengan jumlah responden sebanyak 15 orang $(35,7 \%)$. Dapat dilihat dari tabel di atas bahwa ada responden yang telah mengecap pendidikan D3/S1 sebanyak 3 orang (7,1 \%). Tingkat pendidikan seseorang berpengaruh dalam mengambil keputusan tentang pengembangan usaha yang ditekuni.

\section{Pendidikan Non Formal}

Keragaan peternak dengan pendidikan non formal yang berkaitan terhadap usaha peternakan mereka, telah diikuti petani antara $0-7$ kali. Kegiatan pendidikan non formal yang umumnya telah diikuti oleh peternak adalah pelatihan penggemukan sapi yang diadakan oleh Dinas Peternakan dan Kesehatan Hewan Kabupaten Sinjai.

\section{Jumlah Tanggungan Keluarga Responden}

Peternak sebahagian besar memiliki tanggungan keluarga 3-4 orang berjumlah 21 orang atau 50,0\%, dan ada 3 orang responden $(7.1 \%)$ yang memiliki jumlah tanggungan keluarga sebanyak lebih dari 4 orang. Keterkaitan jumlah tanggungan keluarga dengan keberhasilan dalam mengelola usaha akan mempengaruhi kemampuan berinvestasi tahap selanjutnya (Ahira, 2012). Secara teoritis dapat dikatakan bahwa apabila jumlah anggota keluarga yang besar, maka merupakan beban bagi kepala keluarga untuk memenuhi kebutuhan keluarganya, yang juga berarti merupakan motivasi dalam berusaha(Siagian, 2016).

\section{Pengalaman Responden Sebagai peternak}

Pengalaman peternak responden dalam beternak berkisar anatara 3 - 30 tahun. Secara rinci menunjukkan bahwa sebanyak 4 orang peternak responden sudah beternak lebih dari 27 tahun. Peternak responden terbanyak yaitu 12 responden $(28,6 \%$ ) adalah memiliki pengalaman beternak antara $8-12$ Tahun. Sedangkan. Jumlah Respon terkecil yaitu 3 Orang $(7.1 \%)$ memiliki pengalaman beternak antara $3-7$ tahun.

\section{Lama Responden Mengikuti Program Asuransi Usaha Ternak Sapi (AUTS)}

Dapat dijelaskan bahwa peternak responden telah mengikuti program AUTS dari Dinas Peternakan dan kesehatan Hewan Kabupaten Sinjai dengan interval waktu 1 tahun sampai 3 tahun. keikutsertaan program AUTS 1 tahun sampai 2 tahun adalah jumlah responden peternak terbanyak yaitu sebesar 38 orang (90.5\%), sedangkan jumlah responden terkecil yaitu 4 orang $(9.5 \%)$ adalah dengan lama keikutsertaan program AUTS selama 3 tahun sampai 4 tahun.

\section{Pelaksanaan Program Asuransi Usaha Ternak Sapi (AUTS)}

Kecamatan Tellulimpoe adalah salah satu kecamatan yang memiliki jumlah peserta Asuransi Usaha Ternak Sapi (AUTS) terbanyak di Kabupaten Sinjai (Dinas Peternakan dan Kesehatan Hewan, 2017). Peternak yang berada di kecamatan tellulimpoe telah ikut serta dalam program AUTS sejak adanya program ini sampai sekarang. Jumlah peternak yang menjadi peserta AUTS selama tiga tahun terakhir dapat dilihat pada Grafik dibawah:

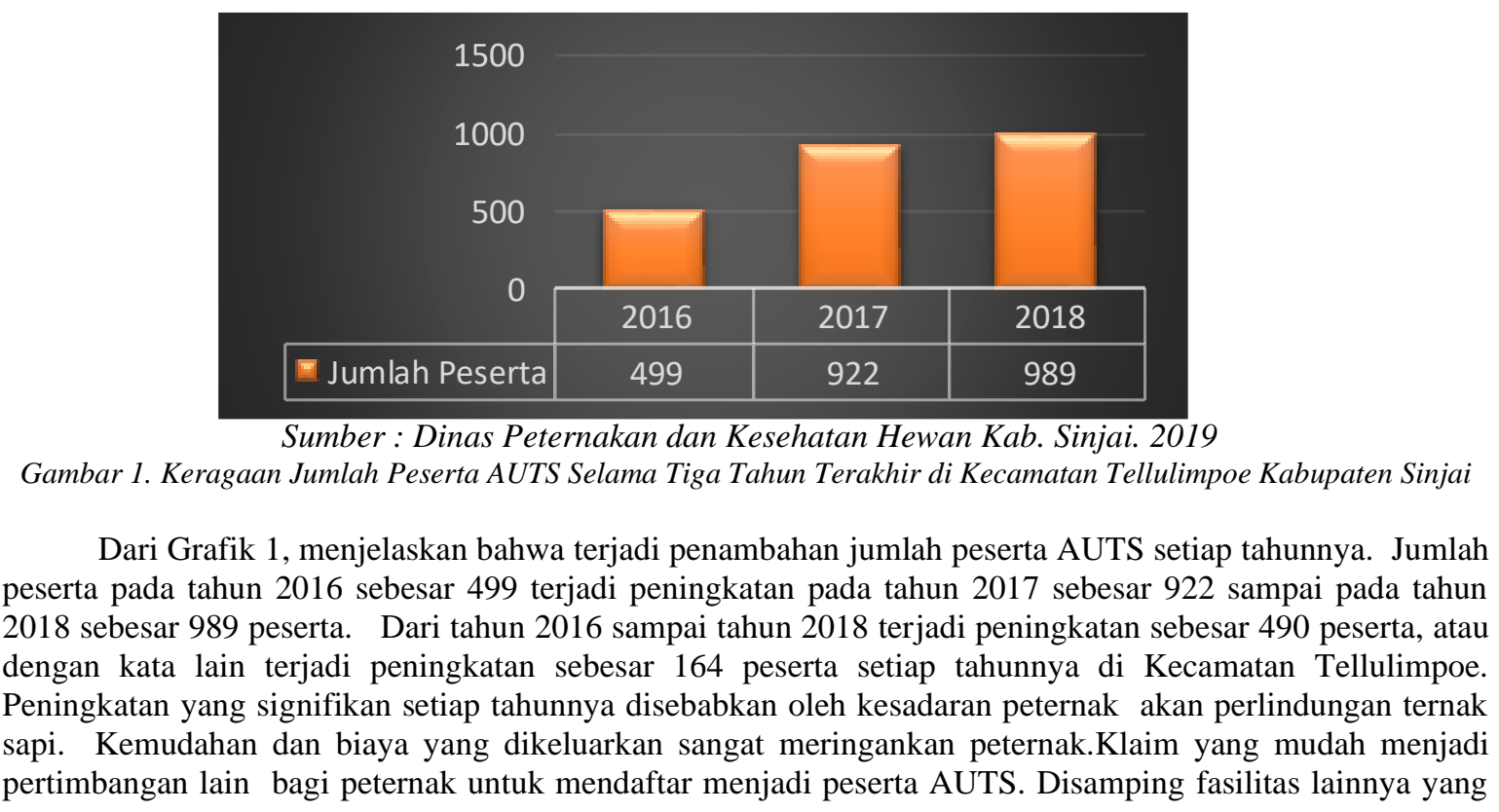


di tawarkan oleh pemerintah setempat dalam hal ini Dinas Peternakan dan Kesehatan Hewan Kabupaten Sinjai.

Total klaim AUTS di Kecamatan Tellulimpoe sampai tahun 2018 sebanyak 47 klaim. Pada Tahun 2017, terdapat 17 klaim peserta AUTS dan $100 \%$ klaim tersebut terbayar, sedangkan pada tahun 2018 terdapat 30 klaim akan tetapi hanya 28 klaim $(93,33 \%)$ yang dapat dibayarkan. Tidak semua peternak sapi mendapatkan manfaat perlindungan dari asuransi ternak ini. Terdapat beberapa kriteria calon penerima polis, baik pelaku usahanya maupun kriteria ternak sapi merupakan pelaku usaha penggemukan dan pembibitan sapi potong.

\section{Motivasi Peternak Sapi dalam Mengikuti Program AUTS}

Secara umum motivasi peternak sapi dalam mengikuti AUTS dapat dikatakan tinggi dengan rataan skor 2,65. Motivasi peternak ini muncul karena peternak merasa dengan ikut dalam AUTS, usahaternak sapi akan mampu mendukung hubungan sosial mereka dan biasa dikembangkan sebagai usaha keluarga meskipun motivasi peternak ini juga kurang bisa mendukung dalam memenuhi kebutuhan dasar. Hal ini dapat dilihat pada Tabel berikut.

Tabel 2. Rataan skor berdasarkan motivasi peternak dalam mengikuti program AUTS di Kecamatan Tellulimpoe Kabupaten Sinjai

\begin{tabular}{lcc}
\hline \multicolumn{1}{c}{ Aspek Motivasi } & Rata-rata & Keterangan \\
\hline Kebutuhan Dasar & 2.33 & $1-1,66=$ Rendah, \\
Hubungan Sosial & 2.68 & $1,67-2,33=$ Sedang, \\
Pengembangan Usaha & 2.95 & $2,34-3,00=$ Tinggi \\
\hline \multicolumn{1}{c}{ Total rataan Skor } & 2.65 & \\
\hline
\end{tabular}

Sumber: Data Primer Setelah Diolah, Tahun 2019

Kebutuhan dasar adalah kebutuhan penting bagi peternak yang memberikan kontribusi besar dalam kebutuhan keluarga peternak. Secara umum peternak dalam memenuhi kebutuhan dasar dapat dikatakan sedang dengan rataan skor 2,33. pembelian bahan makanan yang dilakukan oleh peternak untuk kebutuhan konsumsi keluarga sehari-hari terkategori rendah dengan rataan skor 1,74. Hal ini dikarenakan usahaternak sapi di Kecamatan Tellulimpoe hanya sebatas pekerjaan sambilan dan skalanya masih kecil sehingga hasil yang didapatkan masih belum mencukupi kebutuhan yang dikonsumsi sehari-hari.

Hubungan sosial adalah kebutuhan peternak untuk memperoleh kebutuhan sosial dan kebutuhan prestise (status). Hal ini menjadi salah satu motivasi peternak dalam mengikuti proran AUTS. Secara umum peternak dalam memenuhi hubungan sosial dapat dikatakan tinggi dengan rataan skor 2,68. Peternak merasa dengan mengikuti program AUTS, mereka dapat diterima di kelompok ternak dengan kategori tinggi yang mempunyai rataan skor 2,83. Pada hakekatnya dalam kehidupan kelompok peternak di Indonesia sudah cukup terpenuhi karena sifat kekeluargaan sudah menjadi dasar hidup bangsa indonesia dalam hubungan seseorang dengan kawan-kawannya (Handoko, 1992). Peternak merasa diterima apabila peternak dapat dilibatkan dalam kegiatan rutin kelompok (Muatip, 2008), bisa mendapatkan bantuan dari Dinas Peternakan dan Kesehatan hewan. Peternak merasa dari keikutsertaan program AUTS dapat meningkatkan kedudukan peternak di kelompok dan masyarakat dengan rataan skor 2,64.

Sedangkan secara umum peternak dalam mengembangkan usaha ternak sapi dapat dikatakan tinggi dengan rataan skor 2,95. Pengembangan usaha ternak ini juga sejalan dengan tujuan utama dari beternak sapi adalah meningkatkan pendapatan peternak sehingga kesejahteraan peternak dapat tercapai(Sri Wahyuni, 2017). Salah satu motivasi peternak sapi di Kecamatan Tellulimpoe dalam mengikuti program AUTS adalah dengan ikut serta dalam program tersebut merasa dapat meningkatkan kemampuan beternak sapi. Keterbatasan ilmu pengetahuan tentang seluk beluk ternak sapi menjadikan kendala bagi usaha ternak (Maryati, 2009), sehingga pengembangan usahaternak di daerah ini belum optimal. Dengan mengikuti program AUTS, peternak memiliki akses informasi yang luas terhadap pengetahuan dan informasi yang berasal dari petugas peternakan. Hal ini dapat mendorong peternak meningkatkan kemampuan mereka dalam beternak sapi.

\section{Faktor Eksternal Peternak Responden}

Faktor eksternal adalah kondisi di luar diri peternak yang dapat mendukung Peternak dalam keikutsertaannya dalam program tertentu (Soekartawi, 1993), termasuk program Asuransi Usaha Ternak Sapi (AUTS). Faktor eksternal peternak sapi Potong di Kecamatan Tellulimpoe mencakup pasaran untuk usaha ternak, teknologi, sarana dan peralatan produksi, perangsang produksi, dan pengangkutan.

Secara umum faktor eksternal peternakan Sapi di Kecamatan Tellulimpoe dinilai mudah oleh para peternak dengan rataan skor 2,84 yang menunjukkan bahwa para peternak sudah merasakan kemudahan dalam memperoleh faktor-faktor tersebut setelah mereka mengikuti program AUTS. Dengan demikian 
faktor-faktor eksternal tersebut sudah cukup mendukung peternak dalam mengembangkan usaha ternak sapi potong mereka. Hal ini dapat dilihat pada Tabel.

Tabel 3. Rataan skor berdasarkan faktor eksternal peternak sapi setelah keikutsertaan dalam AUTS di Kec. Tellulimpoe Kab. Sinjai

\begin{tabular}{lcl}
\hline \multicolumn{1}{c}{ Faktor Eksternal } & Rata-rata & \multicolumn{1}{c}{ Keterangan } \\
\hline Pasar Untuk Usahaternak & 2.88 & $1-1,66=$ sangat Sulit, \\
Teknologi & 2.93 & $1,67-2,33=$ Sulit, \\
Sarana dan Alat Produksi & 2.83 & $2,34-3,00=$ mudah \\
Perangsang produksi & 2.84 & \\
Pengangkutan & 2.75 & \\
\hline \multicolumn{1}{c}{ Total rataan Skor } & $\mathbf{2 . 8 4}$ & \\
Sumber : Data Primer Setelah Diolah, Tahun 2019 &
\end{tabular}

Berdasarkan Tabel diatas, terdapat perbandingan faktor eksternal yang meliputi faktor perangsang produksi, pengangkutan, sarana dan alat produksi, dan pasaran untuk usaha ternak sapi dirasakan mudah oleh peternak setelah mendapatkan program AUTS dalam mendukung upaya pengembangan usaha peternakan sapi. Artinya peternak sudah dapat memanfaatkan faktor-faktor tersebut secara mudah.

\section{Faktor-Faktor yang Berhubungan dengan motivasi Peternak Dalam Mengikuti Program Asuransi Usaha Ternak Sapi (AUTS) \\ Faktor Internal Peternak}

Karakterisitik peternak yang berhubungan dengan motivasi peternak dalam mengikuti program AUTS adalah umur, pendidikan, lama beternak dan jumlah tanggungan. Analisis hubungan karakterisitk peternak dengan motivasi peternak diolah dengan menggunakan analisis rank Spearman. Hasil analisis korelasi rank Spearman ditampilkan pada Tabel 4 berikut ini.

Tabel 4. Koefisien Korelasi Faktor Internal Peternak Dengan Motivasi Peternak Terhadap Program AUTS di Kecamatan Tellulimpoe Kabupaten Sinjai

\begin{tabular}{lrrr}
\hline \multirow{2}{*}{ Faktor Internal Peternak } & \multicolumn{3}{c}{ Motivasi Peternak terhadap AUTS } \\
\cline { 2 - 4 } & Kebutuhan Dasar & Hub. Sosial & Peng. Usaha \\
\hline Umur & 0,276 & 0,545 & 0,246 \\
Tingkat Pendidikan & 0,318 & 0,234 & 0,705 \\
Lama Beternak & 0,190 & 0,361 & 0,269 \\
Jml. Tanggungan Keluarga & 0,675 & 0,197 & 0,349 \\
\hline
\end{tabular}

Sumber: Data Primer Setelah Diolah, Tahun 2019

Hasil analisis korelasi rank Spearman seperti ditampilkan pada Tabel 4 menunjukkan bahwa motivasi kebutuhan dasar berhubungan nyata dengan jumlah tanggungan keluarga dengan nilai koefisian korelasi sebesar 0,675. Hal ini berarti bahwa semakin banyak jumlah tanggungan keluarga maka akan meningkatkan motivasi peternak untuk memenuhi kebutuhan dasar mereka (Umar, 2003). Kebutuhan dasar dalam hal ini adalah tambahan pendapatan. Rumah tangga yang memiliki anggota cukup banyak maka kebutuhannya pun semakin besar, sehingga diperlukan sumber-sumber tambahan pendapatan. Dengan demikian, usaha beternak sapi menjadi alternatif sumber tambahan pendapatan untuk memenuhi kebutuhan keluarga para peternak di Kecamatan Tellulimpoe. Hal ini sesuai dengan pendapat sebagian besar peternak bahwa berusaha ternak sapi memberikan tambahan pendapatan yang cukup lumayan, selain cukup menguntungkan.

Hubungan antara motivasi masyarakat terhadap program AUTS untuk memenuhi kebutuhan akan hubungan sosial, yaitu kebutuhan peternak untuk diterima dalam pergaulan di lingkungan masyarakat tempat tinggalnya, dengan variabel umur menunjukkan hubungan yang nyata $(\mathrm{P}<0,05 ; \mathrm{r}=0,545)$. Hal ini berarti bahwa semakin meningkat umur peternak maka peternak tersebut semakin memerlukan pemenuhan kebutuhan untuk diterima dalam lingkungan pergaulan tempat tinggalnya. Hal ini dapat dipahami mengingat semakin tua umur seseorang maka semakin peternak tersebut menyadari bahwa hidup itu tidak bisa sendiri, membutuhkan serta dibutuhkan oleh orang lain, terutama orang-orang di sekitar tempat tinggalnya (tetangga). Beberapa peternak di Kecamatan Tellulimpoe yang berusia tua mengakui merasa lebih dekat dengan tetangga yang juga sama-sama peternak sapi. Rasa kedekatan tersebut muncul mengingat para peternak seringkali melakukan aktivitas dan rutinitas yang sama, misalnya ketika bersama-sama mencari rumput, berdiskusi tentang jenis penyakit ternak yang sulit diatasi.

Hubungan antara motivasi peternak mengikuti program AUTS untuk mengembangkan usaha berhubungan nyata dengan tingkat Pendidikan peternak menunjukkan hubungan nyata dengan nilai koifisien korelasi sebesar 0,705. Peternak dengan pendidikan tinggi semakin besar keinginannya untuk melakukan 
pengembangan usaha ternak. Para peternak sangat memahami bahwa pengembangan usaha ternak melalui peningkatan skala usaha akan semakin memberikan peluang untuk meningkatkan pendapatan. Sehingga program AUTS ini menjadi salah satu solusi untuk mengurangi resiko dalam pengembangan usaha. Peternak dengan pendidikan tinggi lebih memahami dan merasa perlu bahwa usahaternak yang dikelola pada saat ini harus ada peningkatan di masa mendatang. Para peternak yang berpendidikan SLTP dan SLTA umumnya bercita-cita suatu saat dapat menjadi pengusaha peternakan besar, dan menjadikan usahaternak sapi sebagai mata pencaharian utama. Kondisi ini berbeda dengan peternak yang lain yang berpendidikan rendah (SD), yang umumnya berpendapat bahwa usaha ternak yang dijalankan pada saat ini sudah cukup, dan tidak berkeinginan untuk menambah skala usahanya, tidak juga bercita-cita menjadi seoarang pengusaha peternakan besar.

\section{Faktor Eksternal Peternak}

Faktor eksternal yang terdiri dari pasaran usahaternak sapi, teknologi, sarana dan alat produksi, perangsang produksi, dan pengangkutan diolahmenggunakan analisis Rank Spearman untuk mencari hubungannya dengan motivasi peternak terhadap program AUTS. Hubungan masing-masing factor eksternal dengan motivasi peternak terhadap program AUTS dapat dilihat pada tabel 5 berikut:

Tabel 5. Koefisien Korelasi Faktor Eksternal Peternak Dengan Motivasi Peternak Terhadap Program AUTS di Kecamatan Tellulimpoe Kabupaten Sinjai

\begin{tabular}{lrrr}
\hline \multirow{2}{*}{ Faktor Ekternal Peternak } & \multicolumn{3}{c}{ Motivasi Peternak terhadap AUTS } \\
\cline { 2 - 4 } & Kebutuhan Dasar & Hub. Sosial & Peng. Usaha \\
\hline Pasar & 0,601 & 0,382 & 0,580 \\
Teknologi & 0,240 & 0,408 & 0,547 \\
Sarana dan Alat Produksi & 0,159 & 0,142 & 0,359 \\
Perangsang Produksi & 0,068 & 0,237 & 0,147 \\
Transportasi & 0,178 & 0,181 & 0,284 \\
\hline
\end{tabular}

Sumber : Data Primer Setelah Diolah, Tahun 2019

Motivasi Peternak dalam mengikuti Progran AUTS dalam aspek kebutuhan dasar, berhubungan kuat dengan faktor Pasar $(0,601)$. Pasar memiliki hubungan nyata dengan motivasi peternak terhadap AUTS yang berkaitan dengan kebutuhan dasar peternak. Nilai koefisien korelasi menunjukkan nilai Korelasi sebesar 0,601. Menunjukkan bahwa harga yang terjamin bagi peternak, nilai jual yang terjamin dan tinggi terhadap hasil ternak sapi akan sangat mempengaruhi tingkat ketersediaan konsumsi peternak. Disisi lainnya peternak akan dapat dengan mudah mengalokasikan pendapatan yang di peroleh dari usaha ternak untuk kebutuhan yang lainnya, seperti perbaikan rumah, dan sebagian bisa untuk di tabung. Sarana dan alat produksi memiliki hubungan rendah dengan aspek kebutuhan dasar dengan nilai korelasi sebesar 0,159. Hal ini menunjukkan bahwa perlengkapan dan peralatan yang dipakai peternak dalam usaha ternak sapi masih tergolong sederhana. Pengadaan sarana dan alat produksi akan berpengaruh terhadap penyediaan kebutuhan peternak kedepan. Setiap biaya yang dikeluarkan akan berdampak terhadap besaran biaya lain yang akan dialokasikan dalam memenuhi kebutuhan dasar peternak. Sedangkan factor perangsang produksi dihubungkan dengan kebutuhan dasar, hanya berkorelasi sangat rendah $(0,068)$.

Motivasi peternak pada Aspek Hubungan Sosial berkorelasi cukup kuat dengan faktor pasar $(0,384)$ dan faktor teknologi $(0,408)$. Peternak yang ikut serta pada program AUTS lebih mudah mendapatkan pengetahuan dan teknologi yang didesiminasikan oleh penyuluh peternakan dan dari sumber lain. Fungsi kelompok sangat optimal sebagai wahana belajar peternak dalam memperoleh informasi dan teknologi baru yang dibutihkan oleh peternak (Muatip, 2008). Demikian halnya dengan informasi pasar (Muatip, 2008). Peternak dapat dengan mudah mendapatkan informasi harga ternak dan dapat menjual ternak dengan mudah, hal ini dikarenakan hubungan yang baik antar sesama peternak memungkinkan akses informasi yang baik.

Sedangkan untuk motivasi peternak mengikuti AUTS dalam Aspek Pengembangan Usaha, Faktor Pasar (0,580) dan factor teknologi $(0,547)$ juga berhubungan cukup kuat. Hal ini menunjukkan bahwa Peternak dalam menerapkan teknologi baru seperti inseminasi buatan, pemberian obat, pemilihan bibit unggul, pemberian pakan sesuai anjuran dapat meningkatkan populasi ternak sehingga berimplikasi terhadap nilai jual ternak dan pengembangan usaha. Begitupun hanya dengan factor sarana dan prasarna dengan nilai korelasi 0,359. Dengan mengikuti program AUTS para peternak akan dengan mudah mendapatkan sarana dan alat produksi yang berasal dari bantuan pemerintah melalui kelompok-kelompok ternak.

Faktor yang memiliki hubungan paling lemah terhadap aspek pengembangan usaha yaitu (perangsang produksi) dengan nilai korelasi sebesar 0,147 (sangat rendah). Karena perangsang seperti ketersediaan barang yang dibutuhkan oleh keluarga peternak didaerah setempat. Dapat berdampak terhadap semakin banyak hasil usaha ternak sapi yang akan dijual agar dapat memperoleh barang-barang tersebut, 
sehingga jumlah ternak yang dimiliki peternak tidak bertambah bahkan cenderung berkurang dan mengakibatkan peternak tidak dapat pengembangkan usaha peternakan mereka.

\section{KESIMPULAN}

Pelaksanaan Program Asuransi usaha Ternak Sapi (AUTS) di Kecamatan Tellulimpoe dilaksanakan secara bertahap dimulai dari sosialisasi, pendaftaran/inventarisasi calon lokasi dan calon peternak (CPCL), verifikasi kelayakan calon peserta, penetapan peserta asuransi, penerbitan sertifikasi polis, pembayaran premi dan pembayaran bantuan premi. AUTS berjalan dengan baik yang ditandai jumlah peserta (sapi) terbanyak di Kabupaten Sinjai yang berjumlah 992 pada Tahun 2017. Dari tahun 2016 sampai tahun 2018 terjadi peningkatan sebesar 490 peserta, atau dengan kata lain terjadi peningkatan sebesar 164 peserta setiap tahunnya. Motivasi Peternak terhadap Program usaha ternak Sapi (AUTS) di Kecamatan Tellulimpoe didasari atas keinginan untuk memenuhi kebutuhan dasar dengan nilai rataan skor responden sebesar 2,33 (tergolong sedang), kebutuhan berhubungan sosial dengan nilai rataan skor responden sebesar 2,68 (tergolong tinggi), dan pengembangan usaha dengan nilai rataan skor responden sebesar 2,95 (tergolong tinggi). Peternak ikut dalam pelaksanaan program AUTS lebih di dasarkan pada motivasi ingin mengembangkan usaha peternakan mereka. Faktor internal peternak yang mempunyai hubungan dalam kategori cukup dengan motivasi peternak dalam mengikuti program AUTS adalah hubungan aspek hubungan sosial dengan umur responden $(\mathrm{r}=0,545)$, hubungan aspek kebutuhan dasar dengan jumlah tanggungan keluarga $(r=0,675)$ dan hubungan aspek pengembangan usaha dengan tingkat Pendidikan $(r=0,705)$. Sedangkan Faktor eksternal yang mempunyai hubungan kuat dengan motivasi peternak mengikuti program AUTS adalah aspek kebutuhan dasar $(0,601)$ dan pengembangan usaha $(0,580)$ adalah factor pasar.

\section{DAFTAR PUSTAKA}

Ahira, A. (2012) Status Sosial Ekonomi Masyarakat. Available at: http/www.acne.ahira/com. Status Sosial Ekonomi Masyarakat. .

Asmirani (2013) Motivasi Peternak Terhadap Aktivitas Budidaya Ternak Sapi Potong di Kabupaten Buru Provinsi Maluku. Universitas Diponegoro.

Balai Pengajian Teknologi Pertanian (BPTP) (2017) 'Dengan Sapi Asuransi Usaha Ternak Sapi (AUTS) Peternak Tenang Memelihara Sapi. Balai Penelitian dan Pengembangan Pertanian Kementrian Pertanian', in. Jambi.

Dinas Peternakan dan Kesehatan Hewan (2017) 'Statistik Peternakan dan Kesehatan Hewan Kabupaten Sinjai', in. Kabuoaten Sinjai.

Handoko, M. (1992) Motivasi Daya Penggerak Tingkah Laku. Yogyakarta: Kanisius.

Maryati, S. (2009) Faktor-Faktor yang Mempengaruhi Preferensi Masyarakat dalam Memiliki Sekolah Menengah Kejuruan Negeri (SMKN) Semarang Program PascaSarjana. Universitas Diponegoro.

Muatip, K. (2008) Kompetensi Kewirausahaan Peternak Sapi Potong Kasus Peternak Sapi Potong Rakyat Pasuruan Jawa Timur. Bandung Jawa Barat.

Nita Adillah Pratiwi (2017) Faktor-faktor Pengambilan Keputusan Keikutsertaan Peternak Sapi Potong dalam Program SPR di Kecamatan Tonra Kabupaten Bone. Makassar: Universitas Hasanuddin.

Rasyid (2006) Metode Penelitian Praktis dan Aplikasinya. Makassar: CV. Amanah.

Siagian, S. . (2016) Manajemen Sumber Daya Manusia. Jakarta: Bumi Aksara.

Siregar (2016) Pengaruh Ransum Komersial terhadap Performa Teknis dan Ekonomis Beberapa Galur Ayam Broiler Umur Lima, Enam, dan Tujuh Minggu. Bogor: Institut Pertanian Bogor.

Soekartawi, A. (1993) Agribisnis Teori dan Aplikasinya. Jakarta: PT. Raja Grafindo Persada.

Sri Wahyuni (2017) Kelayakan Pengembangan Asuransi Usaha Ternak Sapi Potong Mendukung Agribisnis Pedesaan di Wilayah Marginal. Bogor: Pusat Analisis Sosial Ekonomi dan Kebijakan Pertanian.

Syafril. (2017) Asuransi Usaha Ternak Sapi (AUTS) Peternak Tenang Memelihara Sapi. Jambi: Balitbangtan Jambi Balai Penelitian dan Pengembangan Pertanian Kementrian Pertanian.

Umar, H. (2003) Metode Riset Perilaku Konsumen Jasa. Jakarta: Ghalia Indonesia.

Winardi, J. (2004) Manajemen Perilaku Organisasi. Jakarta: Prenada Media. 